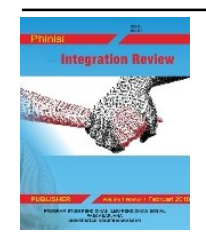

Phinisi Integration Review

Vol. 3, No.2, Agustus 2020 Hal 270-278

Website: http://ojs.unm.ac.id/pir

p-ISSN: 2614-2325 dan e-ISSN: 2614-2317

DOI: https://doi.org/10.26858/v3i2.14920

\title{
Stigma dan Perilaku Bullyng di Madrasah Aliyah Negeri Sinjai Utara
}

\author{
Nurfatmawati ${ }^{1}$, Syamsu Andi Kamaruddin ${ }^{2}$, Ahmadin $^{3}$ \\ ${ }^{123}$ Pendidikan Sosiologi, Universitas Negeri Makassar \\ Email: ${ }^{n}$ urfatmawati025003@gmail.com
}

\begin{abstract}
Abstrak. Stigma dan Perilaku Bullying Di MAN 1 Sinjai Utara Kecamatan Sinjai Utara Kabupaten Sinjai. (Di bimbing oleh Syamsu Andi Kamaruddin dan Ahmadin). Penelitian ini bertujuan untuk mengetahui 1) bentuk stigma dan perilaku bullying di MAN 1 Sinjai Utara. Dan 2) Kebijakan sekolah mengatasi stigma dan perilaku bullying di MAN 1 Sinjai Utara. Jenis penelitian yang digunakan deskriptif kualitatif yang bertujuan untuk menggambarkan stigma dan perilaku bullying di MAN 1 Sinjai Utara, adapun teknik pengumpulan data yaitu melakukan observasi, wawancara, dan dokumentasi. Teknik pengabsahan data yaitu triangulasi sumber yaitu untuk mengkaji kredibilitas data yang dilakukan dengan cara mengecek data yang telah diperoleh melalui beberapa sumber. Dari hasil penelitian ditemukan bahwa (i) Bentuk stigma dan perilaku bullying di MAN 1 Sinjai Utara meliputi tiga bentuk yaitu stigma dan perilaku bullying siswa jurusan IPA ke IPS, stigma dan perilaku bullying guru ke siswa jurusan IPS, pendapat siswa jurusan IPS terhadap guru yang melakukan stigma dan perilaku bullying terhadap siswa jurusan IPS. (ii) Kebijakan sekolah mengatasi stigma dan perilaku bullying di MAN 1 Sinjai Utara meliputi dua kebijakan yaitu pertama kebijakan pusat dalam hal ini kurikulum dan yang ke dua kebijakan sekolah.
\end{abstract}

Kata Kunci: Stigma; Bullying.

Abstract. Stigma and Bullying Behavior at MAN 1 North Sinjai in North Sinjai Subdistrict in Sinaji District (supervised by Syamsu Andi Kamaruddin and Ahmadinn). The study aims at examining 1) the forms of stigma and bullying behavior at MAN 1 North Sinjai and 2) the school policy in overcoming the stigma and bullying behaviot at MAN 1 North Sinjai. The study employs descriptive qualitative, which aims at describing the stigma and bullying behavior at MAN 1 North Sinjai. The techniques used in collecting the data were observation, interview, and documentation. Data validity technique used source triangulation which study the data credibility conducted by chehcking the data obtained through several sources. Based on the results of the study, is discovered (i) the forms ofstigma and bullying behavior at MAN 1 North Sinjai cover three forms, namely stigma and bullying behavior of students of IPA to IPS, stigma and bullying behavior of teachers to IPS students, the perpectives of IPS students on teachers who did the stigma and bullying behavior on IPS students, (ii) the school policy in overcoming the stigma and bullying behavior at MAN 1 North Sinjai cover two policies, namely the first is the central policy in terms of curriculum and the second is the school policy.

Keywords: Stigma; Bullying.

ni adalah artikel dengan akses terbuka dibawah licenci CC BY-NC-4.0

(https://creativecommons.org/licenses/by-nc/4.0/). 


\section{PENDAHULUAN}

Sekolah merupakan tempat seluruh aktivitas proses belajar mengajar yang dilakukan dan sekolah tempat terjadinya interaksi serta sosialisasi antara siswa dengan siswa, siswa dengan guru, siswa dengan satpam sekolah ataupun siswa dengan seluruh pihak yang ada di sekolah. Akan tetapi, sekarang ini banyak terjadi permasalahan di lingkungan sekolah. Saat ini perilaku bullying tidak asing lagi dalam dunia pendidikan di Indonesia baik tingkatan SD, SMP maupun SMA bahkan di bangku perkuliahan atau perguruan tinggi. Bullying (artinya penindasan) adalah perilaku seseorang atau sekelompok orang secara berulang yang memanfaatkan ketidakseimbangan kekuatan dengan tujuan menyakiti targetnya secara mental atau secara fisik.

Guru disekolah bertanggung jawab prestasi akademik dan nilai spritual yang harus di implementasikan oleh siswa. Semestinya sebagai guru menjadi penengah jangan pernah membandingkan antara siswa jurusan IPA dan IPS karena meskipun mengatakan nakal atau malas secara tidak sadar kita telah melakukan stigma yang dapat menimbulkan perilaku bullying secara verbal dapat mengganggu perkembangan siswa jurusan IPS dalam lingkungan sekolah. Siswa jurusan IPS menganggap guru merupakan orang tua di sekolah tetapi kenyataan yang terjadi mereka selalu memberikan pandangan stigma dan perilaku bullying secara verbal yang seperti menganggap siswa jurusan IPS nakal.

Guru seyogyanya mengayomi, mendidik, menjamin keamanan, kenyamanan siswa justru melakukan tindakan kekerasan simbolik terhadap siswa dalam bentuk stigma. Stigma negatif merupakan bentuk gambaran identitas yang diberikan seseorang kepada orang lain dengan melihat melalui persepsi atau penilaian negatif dari kekurangan atau kelebihan seseorang yang ia miliki. Tindakan kekerasan yang diterima oleh para siswa bukan tindakan kekerasan dalam bentuk fisik melainkan tindakan verbal yang berbentuk stigma berupa hinaan dan pemberian julukan. Stigma dan perilaku bullying dapat terjadi disebabkan oleh kurangnya penghargaan guru terhadap siswa jurusan IPS dan sangat menjungjung tinggi penghargaan terhadap siswa jurusan IPA.

\section{TINJAUAN PUSTAKA}

\section{a. Stigma}

Stigma adalah ciri negatif yang menempel pada pribadi seseorang karena pengaruh lingkungannya (KBBI). Menurut Castro dan Farmer (2005) Stigma merupakan salah satu label negatif yang diberikan kepada seseorang karena karakteristik yang bertentangan dengan normanorma dominan masyarakat. Karakteristik ini mungkin fisik, ideologis, atau berasal dari beberapa tindakan yang telah dilakukan atau tidak dilakukan orang tersebut di masa lalu. Orang yang distigmatisasi diberi label lebih rendah dan "ditandai" dalam masyarakat (Gray, 2010). Kemudian stigma juga merupakan suatu karakteristik yang dipertimbangkan tidak diinginkan oleh kebanyakan orang, berbagai pengalaman orang lain dengan niat sengaja atau tidak sengaja memaksa orang yang terstigmatisasi untuk memainkan peran tertentu sebagaimana yang dikehendaki oleh mereka. Bahkan sering terjadi orang melakukan suatu peran yang telah didefiniskan oleh masyarakat bagi mereka (Handayani, 2012).

Jadi dapat disimpulkan bahwa akibat stigma negatif yang diberikan oleh guru terhadap siswa jurusan IPS, membuat siswa jurusan IPA memiliki rasa superioritas dalam diri. Siswa jurusan IPA merasa dirinya lebih pintar dan di senangi oleh guru dari pada siswa jurusan IPS. Stigma yang terjadi dalam dunia pendidikan khusunya pada tingkatan Madrasah Aliyah Negeri (MAN) di sebabkan lemahnya interaksi yang terjadi antara siswa jurusan IPS dengan guru sehingga mengakibatkan hubungan diantara keduanya belum terbangun dengan baik, hal inilah yang menyebabkan munculnya stigma dari guru terhadap siswa jurusan IPS.

\section{b. Perilaku Bullying}

Bullying adalah tindakan sadar dan disengaja yang dimaksudkan untuk merugikan, menimbulkan ketakutan melalui serangan lebih lanjut dan menimbulkan teror (Coloroso, 2006:25).

Bullying mendatangkan efek negatif terhadap korbannya. Bullying yang cepat terlihat dan terkena dampaknya adalah bullying fisik. Misalnya jika anak mendapatkan bullying fisik, akan mendatangkan kerugian fisik seperti sakit dibagian tubuh yang dipukul, memar-memar, hinnga pada kasus ekstrim mendatangkan kematian. Sedangkan dampak dari perilaku bullying verbal dapat mendatangkan efek jangka panjang yaitu, menurunnya kesejahteraan 
psikologis korban dan penyesuaian sosial yang buruk, seperti self-esteem menjadi rendah, konsep diri menjadi negatif, berkurangnya kemampuan menyesuaikan diri dan kecenderungan mengasingkan diri.

Jadi dapat disimpulkan bahwa bullying adalah perilaku yang tidak terpuji, perilaku yang seharusnya tidak boleh dibiarkan merambak dalam dunia pendidikn karena dapat memberikan dampak buruk terhadap perkembangan anak baik secara psikologis maupun sosiologi. Secara psikologis, perkembangan anak dapat tehambat secara psikis dan mental sedangkan secara sosiologis dapat mengganggu perilaku dan perkembangan kepribadian seorang anak baik dalam lingkungan sekolah ataupun lingkungan masyarakat yang luas.

c. Landasan Teori

Kekerasan simbolik adalah salah satu konsep penting dalam ide teoritis Bourdieu. Makna konsep ini terletak Bourdieu menggunakan konsep ini untuk menjelaskan mekanisme yang digunakan kelas atas mendoinasi struktur sosial masyarakat untuk "memaksakan" ideologi, budaya, kebiasaan, atau gaya hidupnya kepada kelompok kelas bawah yang didominasinya.

Menurut Bourdieu dalam (Fachruddin, 2018), kekerasan simbolik terlihat dari upaya aktoraktor kelompok sosial dominan menerapkan suatu makna sosial dan representasi realitas yang diinternalisasikan kepada aktor sebagai sesuatu yang alamiah dan absah, bahkan makna sosial tersebut kemudia dianggap benar oleh aktor lain tersebut. Kemudian kekerasan simbolik merupakan salah satu konsep penting dalam ide teoritis Bourdieu. Makna konsep ini terletak pada upaya aktor sosial dominan menerapkan makna sosial dan representasi realitas yang diinternalisasikan kepada aktor lain sebagai sesuatu alami dan absah, bahkan makna sosial tersebut kemudian dianggap benar oleh aktor lain tersebut.

Kekerasan bahkan tidak dirasakan sebagai bentuk kekerasan sehinga dapat berjalan efektif dalam praktik dominasi sosial. Secara bergantian Bourdieu menggunakan istilah 'kekerasan simbolik', 'kuasa simbolik', dan 'dominasi simbolik' untuk merujuk hal yang sama. Proses ini salah satunya dapat berlangsung melalui proses pembelajatan di sekolah. kekerasan simbolik dapat dilakukan melaui dua cara (Haryatmoko, 2003). Pertama, eufemisme. Eufemisme biasanya membuat kekerasan simbolik menjadi tidak nampak, bekerja secara halus, tidak dapat dikenali, dan dapat dipilih secara "tidak sadar". Bentuk eufemisme dapat berupa kepercayaan, kewajiban, kesetian, sopan santun, dan belas kasihan. Kedua, mekanisme sensorisasi yang menjadikan kekerasan simbolik nampak sebagai bentuk sebuah pelestarian semua bentuk nilai yang dianggap sebagai "moral kehormatan". (Martono, 2012).

\section{METODE}

Penelitian ini menggunakan metode penelitian kualitatif sebagai produser penelitian untuk mendapatkan data deskriptif yaitu sebuah penelitian yang berusaha memberikan gambaran umum mengenai objek yang diamati atau diteliti mengenai fakta yang ada dilapangan tentang stigma dan perilaku bullying di MAN 1 Sinjai Utara.

Adapun lokasi dalam penelitian ini di Madrasah Aliyah Negeri 1 Sinjai Utara karena stigma dan perilaku bullying verbal ini telah terjadi dari sejak peneliti bersekolah di MAN 1 Sinjai Utara.

Sasaran penelitian informan dalam penelitian ini adalah guru, tenaga kependidikan, serta siswa jurusan IPA dan IPS. Pemilihan informan dalam penelitian ini menggunakan cara purposive sampling atau pengambilan data yaitu menentukan kriteria informan yakni guru yang mengajar di sekolah dan bertatap muka langsung dengan siswa baik di dalam kelas maupun di lingkungan sekolah, tenaga kependidikan, siswa jurusan IPA dan IPS.

Dalam penelitian ini mengungkap stigma dan perilaku bullying yang tejadi di MAN 1 Sinjai Utara yang dirumuskan oleh peneliti. Sesuai dengan instrumen yang dirumuskan serta ditujukan dalam mengungkap aspek-aspek sebagai berikut; (1) pemahaman guru terhadap stigma dan perilaku bullying; (2) pemahaman siswa terhadap perilaku bullying. Dalam penelitian ini instrument utama adalah peneliti sendiri, yang diketahui oleh subjek atau informan. Adapun alat yang digunakan oleh peneliti yaitu berupa alat tulis, pedoman wawancara, kamera, dan alat perekam.

Jenis data yang digunakan dalam penelitian ini adalah jenis data primer dan sekunder. Data primer dalam penelitian ini adalah hasil observasi dan wawancara dengan informan penelitian yaitu sistem klasifikasi jurusan dan perilaku bullying. Data sekunder adalah data yang sudah tersedia dan diperoleh peneliti dari pihak narasumber.Sumber informan dalam penelititan ini terbagi menjadi 3 (tiga) yaitu sebagai berikut : (1) Informan kunci yaitu 
informan yang bisa membukakan pintu untuk mengenali keseluruhan medan secara luas, dalam hal ini guru. (2) Informan ahli, yaitu informan yang terlibat secara langsung dalam suatu kegiatan atau interaksi, dalam hal ini siswa jurusan IPA dan IPS. (3) Informan biasa, yaitu informan yang mengetahui suatu program atau kegiatan namun ia tidak berpartisipasi langsung dalam program tersebut, dalam hal ini tenaga kependidikan.

Adapun teknik pengumpulan data yang digunakan dalam penelitian ini adalah:

1) Wawancara Mendalam.

Teknik wawancara yang dilakukan adalah dengan melakukan tanya jawab langsung kepada informan yang berdasarkan pada tujuan penelitian. Teknik wawancara yang dilakukan penulis adalah dengan cara mencatat berdasarkan pedoman pada daftar pertanyaan yang telah di siapkan sebelumnya.

2) Observasi.

Dengan melakukan pengamatan dan pencatatan secara langsung terhadap hal yang di anggap berhubungan dengan objek yang diteliti, atau hal yang berkaitan dengan masalah penelitian.

\section{3) Dokumentasi}

Dokumentasi yang di maksudkan penulis disini adalah peninggalan tertulis seperti arsiparsip dan termasuk juga buku, teori, dalil atau hukum-hukum, dan lain-lain yang termasuk dengan masalah penelitian.

Data yang diperoleh dari hasil penelitian akan dianalisis secara kualitatif, data yang diperoleh di lapangan, diolah kemudian disajikan dalam bentuk tulisan. Dalam peneitian ini proses analisis data yang digunakan adalah sebagai berikut :

1) Reduksi data, peneliti menyaring data yang diperoleh pada saat melakukan penelitian, baik itu pada saat wawancara dengan guru, siswa jurusan IPA dan IPS, dan tenaga kependidikan.

2) Penyajian data, peneliti menyajikan data secara keseluruhan dari hasil penelitian.

3) Kesimpulan, merupakan proses untuk menjawab permasalahan dan tujuan penelitian yakni stigma dan perilaku bullying di Madrasah Aliyah Negeri 1 Sinjai Utara.

\section{HASIL DAN PEMBAHASAN}

\section{1) Bentuk Stigma dan Perilaku bullying di MAN 1 Sinjai Utara}

Stigma dan Perilaku Bullying Siswa Jurusan IPA ke IPS. Stigma merupakan salah satu istilah Bahasa Indonesia yang berarti salah satu sikap negatif yang menempel pada pribadi seseorang karena pengaruh lingkungannya, sikap ini cenderung menuduh seseorang lebih rendah dari pada dirinya. Dikalangan masyarakat sering kita menemui kasus stigma antara seseorang terhadap orang lain ataupun suatu lembaga terhadap lembaga yang lain, namun demikian terkadang beberapa orang tidak menyadari bahwa apa yang mereka lakukan termaksud kategori stigma, karena penggunaan kata "stigma" ini jarang digunakan dalam percapakan sehari-hari dengan kata lain stigma hampir sama maknanya dengan memberikan sebuah julukan terhadap seseorang.

Efek negatif yang sering ditimbulkan dari perilaku stigma ini adalah perilaku bullying verbal. Bullying pada dasarnya tindakan yang sadar dan sengaja yang dimaksudkan mempermalukan dan membuat seseorang merasa tidak nyaman dengan lingkungan sekitarnya. Perilaku bullying bisa terjadi dimana saja misalnya di rumah, sekolah, bahkan di tempat kerja, hal ini pastinya akan sangat mempengaruhi psikis dan kehidupan sosial seseorang yang menjadi korban dari perilaku bullying. Namun akhir ini maraknya kasus bullying ini terjadi dilingkungan sekolah dan memberikan dampak yang sangat buruk terhadap siswa di sekolah.

Salah satu fakta yang terjadi di MAN 1 Sinjai Utara, di Madrasah dapat kita jumpai stigma dan kasus perilaku bullying terjadi antara para siswa yang ditimbulkan karena adanya perbedaan jurusan antara IPA dan IPS. Dengan adanya perbedaan itu terkadang membuat siswa yang satu merasa lebih baik dalam segi prestasi akademik maupun ekstrakulikuler.

Seperti saat ini di Madrasah jurusan IPA merasa bahwa dirinyalah yang paling mampu menaati segala peraturan dan kedisiplinan sekolah sehingga mereka dengan mudahnya memberikan stigma dan perilaku bullying verbal kepada jurusan IPS yang mereka anggap sangat sulit diatur. Stigma dan perilaku bullying tidak bisa dielakkan atau dianggap tidak ada yang terjadi di lingkungan sekolah karena pada fakta yang terjadi di Madrasah sebagaimana yang dikatakan oleh salah satu siswa jurusan IPA yang namanya disingkat $\mathrm{Au}$ pada saat wawancara :"Sikap dan interaksinya anak IPS dengan kami anak IPA cukup baik tapi kalau masalah perilakunya lebih sopan kami anak IPA biasanya itu kalau jam pelajaran anak IPS sering diluar kelas padahal ada gurunya baru bu klu mau juga 
dibilang masalah kedisiplinannya anak IPS masih kurang sekali masih belum bisa menyadari dirinya sebagai siswa di sekolah, mereka itu santai sekali bu tidak merasa bersalah kalau sudah melanggar". (wawancara tanggal 23 januari 2020).

Dari pernyataan diatas yang disampaikan, dapat kesimpulan bahwa fenomena stigma dan perilaku bullying verbal terjadi di lingkungan Madrasah berada dikalangan antar siswa jurusan IPA dan IPS, karena siswa jurusan IPA merasa bahwa mereka jauh lebih baik dibandingkan dengan siswa jurusan IPS dengan mematuhi segala peraturan dan kedisiplinan Madrasah sehingga mereka dengan mudahnya memberikan stigma terhadap siswa jurusan IPS.

Yang melekat diingatan dan fikiran mereka bahwa siswa jurusan IPS itu selalu bolos, manjat pagar, dan terlambat sehingga dari stigma menimbulkan perilaku bullying verbal dikalangan sesama siswa antar jurusan IPA yang diberikan untuk siswa jurusan IPS. Karena siswa jurusan IPA memiliki sosialisasi dan pendekatan yang baik dengan guru sehingga mereka selalu beranggapan bahwa mereka lebih baik dan bisa diandalkan oleh guru.

Siswa jurusan IPA lebih diandalkan di setiap kegiatan sekolah dibandingkan siswa jurusan IPS karena guru hanya memberikan ruang bagi siswa yang dekat dengan dirinya, membuat siswa jurusan IPA memiliki modal atau peluang yang besar di ruang lingkup Madrasah sehingga siswa jurusan IPS merasa mereka tidak diberikan ruang dalam kegiatan di Madrasah baik dalam prestasi akademik maupun ektrakulikuler serta siswa jurusan IPS dipandang tidak pantas dalam mengikuti kegiatan di sekolah.

Stigma dan perilaku bullying guru ke siswa Jurusan IPS. Fenomena stigma dan perilaku bullying seperti ini tidak hanya terjadi antar siswa saja bahkan sebagian guru juga melakukan hal tersebut terhadap siswa, yang tidak semestinya dilakukan oleh seorang guru sebagai pendidik dan pengganti peran orang tua siswa di Madrasah. Seperti statement yang dilontarkan oleh salah satu guru di MAN 1 Sinjai yaitu ibu HR dari hasil wawancara :"Kalau saya lihat dari segi akademik lebih menonjol IPA karena IPA lebih besar kesadarannya dibandingkan dengan IPS, maksudnya IPA lebih sadar terhadap pendidikan sehingga dari segi belajarnya itu lebih bagus dibanding IPS. Anak IPA juga mudah diatur dan kemauan belajarnya lebih besar sedangkan anak IPS lebih dominan santainya dalam mengerjakan tugas-tugas mereka sebagai seorang siswa mungkin dikarenakan dari latar belakang ilmunya sehingga membuat mereka memiliki motivasi belajar yang kurang, selain itu IPA lebih kuat persaingan belajarnya sedangkan IPS paling tidak menonjol persaingan belajarnya itu yang membedakan. (Wawancara tanggal 16 Januari 2020)

Berdasarkan hasil wawancara dari guru dapat ditarik bahwa stigma dan perilaku bullying di MAN 1 Sinjai dilakukan oleh sebagian guru benar adanya, karena sebagian guru siswa jurusan IPA lebih mendominasi seperti prestasi akademik dan ekstrakulikuler. Statment seperti itu guru telah memberikan pandangan buruk terhadap siswa jurusan IPS, dan membuat siswa jurusan IPS tidak diberikan kesempatan untuk berkembang lebih baik karena adanya sikap guru terhadap mereka yang kurang baik di lingkungan Madrasah. Sebagian guru memberikan statment bahwa siswa jurusan IPA memiliki kreativitas lebih baik dari pada siswa jurusan IPS karena setiap kegiatan porseni dilakukan yang mendominasi meraih juara adalah siswa jurusan IPA.

Bahwasanya dari dulu sebagian guru memberikan stigma dan perilaku bullying verbal terhadap jurusan IPS. Ini dibuktikan dengan hasil wawancara dengan ibu $\mathrm{Hr}$ dan bapak Ai yang telah mengajar sekitar 20 tahun.

Menurut ibu ini bahwa siswa jurusan IPA lebih mendominasi dalam hal kedisiplinan. Baik dalam lingkup proses pembelajaran maupun terhadap mematuhi peraturan sekolah dan ini sudah berlangsung sejak ibu tersebut mengajar di MAN 1 Sinjai. Sedangkan menurut bapak Ai bahwa siswa Jurusan IPS yang sering kedapatan manjat pagar, bolos, dan tidak disiplin, berbeda dengan siswa jurusan IPA yang lebih mematuhi terhadap peraturan Madrasah baik di dalam kelas maupun di luar kelas. Selain dari pada itu siswa jurusan IPA sangat mudah diatur dalam proses pembelajaran dan hubungan antara siswa jurusan IPA dekat ini dibuktikan dengan interkasi yang mereka lakukan setelah proses pembelajaran dalam kelas lebih intens. Jadi dapat disimpulkan bahwa sebagian guru selalu memberikan stigma dan perilaku bullying verbal terhadap siswa jurusan IPS dan itu sudah menjadi kebiasaan sebagian guru ketika melihat siswa jurusan IPS melakukan kesalahan, mereka tidak memberikan statment yang baik untuk memotivasi dan merangkul siswa jurusan IPS agar tidak melakukan kesalahan yang sama. 


\section{Pembahasan}

\section{1) Bentuk Stigma dan Perilaku Bullying Verbal di MAN 1 Sinjai Utara}

Stigma dan perilaku bullying verbal saat ini tidak dapat dielakkan dalam dunia pendidikan, karena fakta yang terjadi di MAN 1 Sinjai Utara benar adanyaa stigma dan perilaku bullying antara siswa jurusan IPA dan IPS. Hal ini diketahui dari beberapa pernyataan informan bahwa benar terjadinya stigma dan perilaku bullying antar sesama siswa. Siswa jurusan IPA menganggap bahwa mereka lebih unggul dalam segala hal seperti mematuhi peraturan yang ada di Madrasah, prestasi dalam bidang akademik, prestasi dalam bidang ekstrakulikuler, serta memiliki pendekatan yang baik kepada guru yang ada di Madrasah. Yang melekat diingatan siswa jurusan IPA bahwa siswa jurusan IPS yang selalu kedapatan bolos, manjat pagar, dan terlambat. Sehingga dari stigma menimbulkan perilaku bullying verbal dikalangan siswa jurusan IPS.

Siswa jurusan IPA tanpa disadari menimbulkan sekat ke siswa jurusan IPS, karena siswa jurusan IPA selain unggul di beberapa bidang, mereka tidak terlalu bersosialisasi dengan siswa jurusan IPS dikarenakan adanya stigma kepada siswa jurusan IPS. Berdasarkan hasil penelitian bahwa Stigma dan perilaku bullying antar siswa jurusan IPA dan IPS yang terjadi di Madrasah karena faktor kekerasan simbolik yang terdapat tiga macam faktor salah satunya yaitu modal. Modal merupakan serangkaian kemampuan atau keahlian individu termaksud didalamnya adalah sikap, cara bertutur kata, berpenampilan, dan cara bergaul. Modal pada dasarnya berupa keyakinan akan nilia-nilai (values) mengenai segala sesuatu yang dipandang benar dan senantiasa diikuti dengan upaya untuk mengaktualisasikannya. Modal disini dimaksudkan sebagai semua bentuk pengakuan oleh kelompok baik secara institusional atau non institusional. (Martono, 2012:32).

Dalam hal ini modal simbolik yang dimaksudkan sebagai semua bentuk pengakuan oleh kelompok, baik secara institusional atau non-institusional. Simbol itu sendiri memiliki kekuatan untuk mengkontruksi reaalitas, yang mampu menggiring orang untuk mempercayai, mengakui, dan mengubah pandangan mereka tentang realitas seseorang, atau sekelompok orang. Modal merupakan salah satu faktor yang lebih mengarah ke stigma dan perilaku bullying verbal, seperti yang terjadi di MAN 1 Sinjai dimana siswa jurusan IPA merasa memiliki sebuah modal bahwa serangkaian kemampuan atau keahlian mereka didalam berperilaku, bertutur kata, berpenampilan, dan cara bergaul di Madrasah mereka merasa paling mematuhi peraturan, kedisiplinan Madrasah serta memiliki prestasi, dan kreativitas yang lebih baik dibandingkan siswa jurusan IPS sehingga guru yang berada di Madrasah berfikiran bahwa siswa jurusan IPA lebih layak dibanggakan dalam segala hal baik dalam lingkup Madrasah maupun diluar Madrasah.

Stigma dan perilaku bullying guru terhadap siswa jurusan IPS. Sebagian guru di Madrasah beranggapan bahwa siswa jurusan IPA lebih mendominasi dalam hal seperti prestasi akademik, ekstrakulikuler, kreativitas, kedisiplinan terhadap peraturan Madrasah, sikap dan perilaku, serta mudah diatur baik dalam kelas maupun diluar kelas, dan mengikuti setiap kegiatan yang mendominasi adalah siswa jurusan IPA sedangkan guru menginginkan siswa jurusan IPS harus mampu seperti siswa jurusan IPA yang mudah diatur. Stigma dan perilaku bullying ini terjadi di MAN 1 Sinjai yang dilakukan oleh sebagian guru merupakan kekerasan simbolik salah satu faktornya ialah habitus. Habitus merupakan hal yang sudah menjadi kebiasaan sebagian guru melakukan terhadap siswa jurusan IPS. Habitus adalah sebuah sistem disposisi (skema persepsi pikiran, dan tindakan yang diperoleh dan bertahan lama). Habitus juga merupakan gaya hidup, nilai-nilai, watak, dan harapan kelompok sosial tertentu. Sebagian habitus dikembangkan melalui pengalaman. Individu belajara tentang apa yang berada diluar kehidupan, sebagaimana mereka berhasil dalam berbagai kegiatan, bagaimana orang lain merespon aktivitas dirinya jika mereka melakukan cara yang tidak biasanya (Martono, 2012).

Habitus mendasari terhadinya kehendak merespon, merasa, berfikir, bertindak, dan bersosialisasi dengan individu yang lain, lingkungan luar diri maupun berbagai perlengkapan yang menyertai diri. Fakta yang terjadi di MAN 1 Sinjai dalam kebiasaan sebagian guru seiring dengan pengertian habitus bahwa stigma dan perilaku bullying sudah menjadi kebiasaan bagi sebagian guru melakukan hal tersebut terhadap siswa jurusan IPS. Sebagian guru selalu menyudutkan siswa yang melakukan kesalahan, guru hanya mengingat kesalahan yang dilakukan siswa jurusan IPS tanpa melihat dari 
sisi baik siswa jurusan IPS. Serta guru cenderung susah untuk merubah kebiasaan lamanya dan selalu terbawa dengan apa yang ada di benaknya tanpa mempertimbangkan bahwa ucapan yang dilontarkan akan berdampak negatif terhadap perkembangan psikologis dan kehidupan sosial siswa jurusan IPS di lingkungan Madrasah.

Seharusnya sebagai seorang guru yang memiliki peran penting didunia pendidikan dan peran penting sebagai orang tua di Madrasah berusaha memberikan perlakuan baik dan bertutur kata yang baik dengan siswa jurusan IPS karena apabila mereka melakukan sebuah kesalahan lalu guru melontarkan tutur kata yang kurang baik dan perlakuan kurang baik seperti membeda-bedakan antara siswa jurusan IPA dan IPS atau lebih membanggakan siswa jurusan IPA dari pada siswa jurusan IPS memiliki dampak yang sangat buruk terhadap psikis dan kehidupan sosial siswa jurusan IPA baik dilingkungan Madrasah maupun diluar Madrasah. Idealnya tugas seorang guru adalah mendidik, membimbing, merangkul, dan mencontohkan yang baik sehingga siswa dapat menjadikan guru sebagai tokoh panutan mereka baik status mereka masih sebagai siswa di Madrasah maupun mereka yang telah menjadi alumni. karena siswa pada umumnya hanya mengingat kepada guru yang mereka merasa dirangkul dan dihargai.

Seorang guru seharusnya banyak mendengar keluhan dari siswa dan memberikan motivasi untuk siswa. Dan paling penting adalah guru harus memberikan kesempatan yang sama terhadap siswa untuk mengembangkan kemampuan mereka tanpa melihat jurusan siswa tersebut.

Pendapat Siswa jurusan IPS terhadap guru yang memberikan stigma dan perilaku bullying terhadap jurusan IPS. Berdasarkan hasil wawancara sebelumnya dapat disimpukan bahwa siswa terkadang telah lama yang dilakukan oleh siswa. Seharusnya hal ini tidak perlu dilakukan oleh guru karena apabila dalam proses pembelajaran guru kurang berusaha untuk memperbaiki perilaku mereka dan berusaha untuk mengikuti proses pembejalaran dengan baik, namun guru memberikan respon yang kurang baik seperti guru dalam kelas selalu marah tanpa alasan yang hanya mengingat pelanggaran yang dibuat interaktif kepada siswa maka akan berdampak kepada hasil belajar siswa. Siswa mengharapkan agar guru memberikan perilaku yang di senangi serta sikap yang adil terhadap kedua jurusan tersebut. Guru memberikan kesempatan kepada siswa untuk mengutarakan alasannya mengapa siswa melakukan pelanggaran tersebut. Seharusnya guru tidak membandingkan potensi yang dimiliki oleh siswa jurusan IPA dan IPS, karena potensi yang dimiliki oleh setiap siswa itu berbeda.

\section{2) Kebijakan Sekolah Mengatasi Stigma dan Perilaku bullying}

a) Kebijakan Pusat dalam hal kurikulum

Kurikulum saat ini dirasakan mempunyai peran dan fungsi yang kompleks. Hal tersebut karena kurikulum merupakan alat yang krusial dalam merealisasikan program pendidikan, baik formal maupun non formal, sehingga gambaran sistem pendidikan dapat terlihat jelas dalam kurikulum tersebut.

Kurikulum telah mengimplementasikan kebijakan bahwa stigma dan perilaku bullying di dunia pendidikan tidak diperbolehkan. seperti halnya kebijakan yang ditetapkan oleh kurikulum, mengahapuskan sistem penulisan dan pemberian peringkat di rapor karena dengan adanya penulisan peringkat secara tidak langsung kurikulum membiarkan stigma dan perilaku bullying terjadi di dunia pendidikan. Serta kurikulum mengimplentasikan kebijakan yang tetapkan bahwa siswa jurusan IPS dapat memilih pelajaran ada di jurusan IPA seperti biologi, kimia, dan fisika begitupun sebaliknya dalam hal ini kurikulum menetapkan kebijakan adanya lintas minat.

b) Kebijakan dalam Sekolah

Bahaya Stigma dan perilaku bullying. Cara mensosialisasikan ke guru menegaskan pada saat pertemuan seperti rapat dan pada saat upacara, mensosialisasikan bahwa stigma dan perilaku bullying yang dilakukan oleh guru kepada siswa jurusan IPS dan membedakan antara kedua jurusan tersebut tidak di perbolehkan. Dengan kebijakan ini pihak Madrasah telah berusaha mengimplementasian kebijakan yang di buat oleh pusat tercantum dalam kurikulum. Seharusnya sebagai pendidik tidak membedakan kemampuan siswa, karena setiap siswa memiliki kemampuan yang berbeda.

Kepala Madrasah dan Wakamad Kurikulum memberikan contoh. Kebijakan yang lain diimplementasikan oleh Kepala Madrasah dan wakamad kurikulum langsung memberikan contoh kepada guru bahwa stigma dan perilaku bullying terjadi di Madrasah tidak diperbolehkan. Sebelum menetapkan kebijakan di Madrasah terlebih dahulu Kepala Madrasah dan wakamad kurikulum yang harus melakukan, sebab mereka 
menjadi contoh yang wajib di tauladani di Madrasah. Kepala MAN 1 Sinjai Utara dan wakamad secara bertahap mengupayakan mengimplementasikan dari pusat dalam hal ini kurikulum, untuk menghilangkan stigma dan perilaku bullying verbal yang terjadi di MAN 1 Sinjai utara, berupaya aktif mensosialisasikan dengan guru tentang bahaya label atau stigma dan perilaku bullying di Madrasah.

Salah satu yang mempengaruhi pencapaian dari proses pendidikan adalah faktor psikologis dan kehidupan sosial siswa. Jika kedua faktor tersebut tidak sejalan maka menyebabkan faktor yang lainnya pun akan berdampak negatif. Pelabelan atau stigma dan perilaku bullying tidak di perbolehkan sebab dapat membuat siswa jurusan IPS bersikap seperti dengan pelabelan atau stigma dan perilaku bullying verbal yang di berikan oleh guru kepada siswa tersebut.

\section{SIMPULAN DAN SARAN}

1. Bentuk stigma dan perilaku bullying di MAN 1 Sinjai Utara meliputi tiga bentuk seperti, sebagai berikut yaitu. Pertama, Stigma dan perilaku bullying verbal siswa jurusan IPA terhadap siswa jurusan IPS, dimana siswa jurusan IPA dengan sistem pendekatan yang interaktif dengan guru merasa memiliki modal memberikan stigma dan perilaku bullying verbal kepada siswa jurusan IPS. Kedua, yaitu stigma dan perilaku bullying verbal guru ke siswa jurusan IPS yaitu sebagian guru selalu memberikan stigma dan perilaku bullying verbal terhadap siswa jurusan IPS sudah menjadi kebiasaan sebagian guru. Ketika melihat siswa jurusan IPS melakukan kesalahan, mereka tidak memberikan statment yang baik untuk memotivasi dan merangkul siswa jurusan IPS agar tidak melakukan kesalahan yang sama. Ketiga, yaitu pendapat siswa jurusan IPS terhadap guru yang melakukan stigma dan perilaku bullying terhadap jurusan IPS guru tidak memberikan motivasi dan merangkul siswa dalam menuntut ilmu justru mereka mematahkan semangat siswa dalam menuntut ilmu, tidak hanya itu beberapa perlakuan yang tidak adil di terima oleh siswa jurusan IPS, sehingga siswa merasa acuh tak acuh baik dalam proses belajar mengajar maupun bersikap di lingkungan Madrasah. Stigma dan perilaku bullying yang diterima oleh siswa jurusan IPS di Madrasah dapat mengubah pola pikir dan sikap siswa terhadap guru tersebut.

2. Kebijakan sekolah mengatasi stigma dan perilaku bullying di MAN 1 Sinjai Utara meliputi dua kebijakan yaitu yan pertama kebijakan pusat atau nasional dalam hal ini kurikulum, dimana kurikulum telah mengeluarkan sebuah kebijakan seperti halnya telah menghapus penulisan peringkat pada rapor. Kedua kebijakan sekolah ini dibagi menjadi dua bentuk meliputi Mensosialisasikan Bahaya Stigma dan perilaku bullying verbal seperti dengan cara mensosialisasikan kepada guru pada saat pertemuan tertentu misalnya rapat guru dan pada saat upacara. Dan Kepala Madrasah dan Wakamad Kurikulum memberikan contoh, kebijakan dari pihak Madrasah sedang mengupayakan dalam mengatasi stigma dan perilaku bullying verbal yang terjadi di MAN 1 Sinjai secara perlahan telah di jalankan oleh Kepala Madrasah dan Wakamad Kurikulum sebelum menetapkan suatu kebijakan maka yang paling utama harus mengimplementasikan mereka berdua karena mereka sebagai contoh bagi guru dan siswa yang ada di Madrasah.

3. Bagi Kementrian Pendidikan dan Kebudayaan diharapkan agar lebih memperhatikan segala sesuatu yang terjadi di lingkungan sekolah terutama stigma dan perilaku bullying verbal yang tidak hanya terjadi di MAN 1 Sinjai Utara namun hal ini terjadi juga di sekolah lain.

Adapun saran yang dapat diberikan sebagai peniliti sebagai berikut:

1. Bagi Departemen Agama Kabupaten Sinjai diharapkan agar lebih meningkatkan kualitas kinerja guru yang ada di lingkup Madrasah, agar guru lebih memperhatikan sikap dan cara bertutur kata yang baik dengan siswa. Baik siswa jurusan IPA maupun IPS.

2. Bagi Madrasah Aliyah Negeri 1 Sinjai Utara diharapkan agar lebih selalu mengingatkan kepada guru-guru agar lebih mengontrol sikap dan cara bertutur kata kepada siswa baik siswa jurusan IPA maupun IPS. Dan memberikan ruang terhadap siswa jurusan IPS untuk mengembangkan potensi yang mereka miliki.

\section{DAFTAR RUJUKAN}

Castro, A., \& Farmer, P. (2005). Understanding and addressing AIDS-related stigma: from 
Nurfatmawati, Kamaruddin, Ahmadin. Stigma dan Perilaku Bullyng di Madrasah ...

anthropological theory to clinical practice in Haiti. American journal of public health, 95(1), 53-59.

Coloroso, B. (2006). Penindas, Tertindas, dan Penonton; Resep Memutus Rantai Kekerasan Anak dari Prasekolah hingga SMU. Jakarta: Serambi ilmu pustaka.

Fachruddin, F. (2018). Kekerasan Simbolik di Sekolah. Sukma: Jurnal Pendidikan, 2(2), 311-327.

Gray, R. (2010). Shame, Labeling And Stigma: Challenges To Counseling Clients In Alcohol And Other Drug Settings. Contemporary Drug Problems, 37(4), 685-703.

Handayani, A, and N Anissa. "Hubungan Antara Konsep Diri Dan Kematangan Emosi Dengan Penyesuaian Diri Istri Yang Tinggal Bersama Keluarga Suami.” Jurnal Psikologi Pitutur 1, no. 1 (2012).

Haryatmoko, M. K. B. P. (2003). Majalah Basis nomor 11-12. Tahun ke-52, NovemberDesember.

Martono, Nanang. 2012. Sosiologi Pendidikan Pengetahuan, Kekuasaan, Disiplin, Hukuman, dan seksualitas. Jakarta: PT Raja Grafindo Persada. 